ISSN1027-5495. Functional Materials, 23, No.3 (2016), p. 433-436

\title{
The mechanical characteristic of rock salt under uniaxial compression with low temperature effect
}

\author{
Jie Chen ${ }^{1}$, Xilinx Shi ${ }^{1}$, Jiankun Zhou ${ }^{2}$ \\ ${ }^{1}$ Institute of Rock and Soil Mechanics, The Chinese Academy of Science, \\ Wuhan, Hubei 430071, China \\ ${ }^{2}$ State Key Laboratory for the Coal Mine Disaster Dynamics and Controls, \\ Chongqing University, Chongqing 400044, China
}

Received December 28, 2015

\begin{abstract}
The mechanical characteristic of rock salt under uniaxial compression after effected by temperature was studied. The test temperature were $35,50,70^{\circ} \mathrm{C}$. The results shown that: the Stress-strain curve of rock salt effected with low temperature under uniaxial compression process are similar, Which illustrated that the mechanical behavior of the salt rock specimen with room temperature can reflect the characteristics rock salt of rock salt underground. It is means that rock salt under the condition of short-term temperature drying effect, its mechanical characteristics was unchanged. Generally rock salt effected by temperature in the process of uniaxial compression, its acoustic emission ringing shown the similar property. The uniaxial mechanical properties was similar, when the rock salt specimens effected with temperature from 35 to $70^{\circ} \mathrm{C}$.

Keywords: rock salt; mechanical characteristic; acoustic emission (ae); temperature; unaxial compression
\end{abstract}

Изучены механические свойства каменной соли при одноосном сжатии после сушки при невысоких температурах $\left(35,50\right.$ и $\left.70^{\circ} \mathrm{C}\right)$. Установлено, что диаграммы деформации каменной соли, подвергнутой отжигу при данных температурах, подобны. Это свидетельствует, что механические свойства образцов каменной соли, измеренные при комнатной температуре, отражают свойства образцов ископаемой каменной соли, т.е. механические свойства соли не изменяются после сушки. Установлено, что в каменной соли, отожженной при невысоких температурах, наблюдается аналогичный характер эмиссии акустических фононов. Показано, что механические свойства образцов соли, подвергнутых одноосному сжатию после отжига в интервале температур $35-70^{\circ} \mathrm{C}$, являются идентичными.

Вплив температури сушки на механічні властивості кам'яної солі при одновісному стисненні. Цзе Чен, Силинь Ши, Цзянькунь Чжоу

Вивчені механічні властивості кам'яної солі при одновісному стисненні після сушки при невисоких температурах $\left(35,50\right.$ и $\left.70{ }^{\circ} \mathrm{C}\right)$. Встановлено, що діаграми деформації кам'яної солі, яка була відпалена при цих температурах, е подібними. Це свідчить, що механічні властивості зразків кам'яної солі, виміряні при кімнатній температурі, відображають властивості зразків викопної солі, тобто механічні властивості солі не змінюються після сушки. Встановлено, що в кам'яній солі, яка була відпалена за невисоких температур, спостерігається аналогічний характер емісії акустичних фононів. Показано, що механічні властивості зразків солі в умовах одновісного стиснення після відпалу в інтервалі температур $35-70{ }^{\circ} \mathrm{C}$, е ідентичними. 


\section{Introduction}

Constructing energy underground storage group in the rock salt stratum is a important part of the west-east natural gas transmission project, and it is also an important project of our country energy strategy reserve. In regard to the condition of encounter temperature and stress couple effect in the process of geotechnical engineering construction is very common. Aiming at temperature effect and stress affect on the process of rock mass damage evolution[1-6]. Now, many scholars pay attention to the research on specifically for the construction process of energy storage and the aspect of rock salt damage in the operation period $[7,8]$.

This paper, we using acoustic emission technology to monitor the characteristics of rock salt damage evolution under the conditions of uniaxial compression after the temperature effect. And then recording the change rule of acoustic emission ringing count and analyzing the influence different temperature on the damage evolution process of rock salt uniaxial compression. This research have important significance to analyze the analysis of cavity surrounding rock damage during the process of rock salt energy underground storage group construction, and to avoid the damage extension of surrounding rock and so on.

\section{Experimental}

The rock salt specimens used to uniaxial acoustic emission test all come from Pakistan, which is buried deep and high purity. Rock mass present carnation, good light transmittance, and compact structure, the content of soluble about 96.3\% 99.8\% (Soluble content mainly $\mathrm{NaCl}, \mathrm{Na}_{2} \mathrm{SO}_{4}$ ), and the insoluble are mainly clay mineral elements. Rock salt specimens size: $50 \mathrm{~mm} \times 50 \mathrm{~mm} \times 100 \mathrm{~mm}$ cuboid. The main purpose of the experiment is analyzing the changing rule of the acoustic emission signal parameters and the damage evolution characteristic, when the temperature is changing. Consider of engineering practice and in order to analyze the experiment result conveniently, the design for test environment is to place the specimen in a certain temperature to drying 48h. Test design three kinds of temperature $\left[35,50,70^{\circ} \mathrm{C}\right]$, test temperature mentioned in this article refers to these three temperature.

\section{Results and discussion}

3.1 Temperature effect on rock salt uniaxial stress-strain characteristics

Under the condition of three kinds of temperature of six Pakistan high purity rock salt

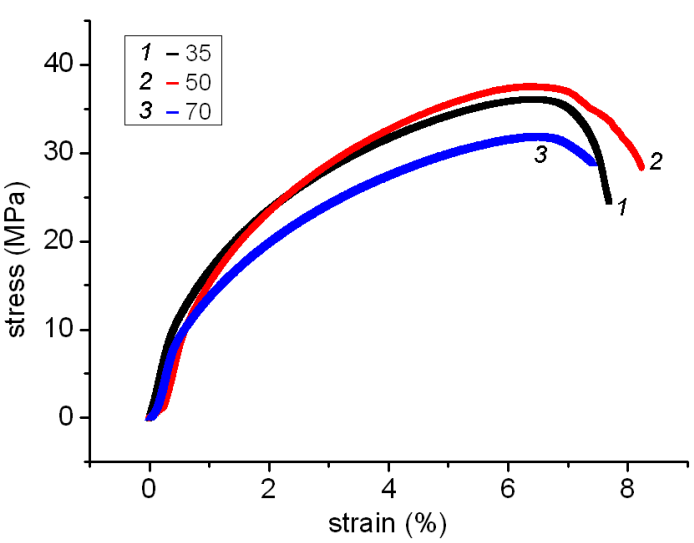

Fig.1 Stress-strain curves of salt specimens

uniaxial compression experiment was carried out, the test results such as Table 1 . From the basic mechanical parameters of the test results, rock salts deformation capacity increase with the rise of temperature, but its effect on rock salts uniaxial compressive strength is not obvious. Its corresponding stress-strain characteristics as shown in Fig. 1

As is show in the test results statistical table 1 and Fig. 1, When the temperature within the scope of 35,35 and $70^{\circ} \mathrm{C}$, Specimen uniaxial stress-strain characteristics of the change is not obvious after two days heat preservation, means after $48 \mathrm{~h}$ baking the regular change of the rock salt specimen uniaxial compressive strength and strain with the temperature change is not obvious.

\subsection{Temperature effect on rock salt uni-} axial acoustic emission characteristics

Rock mass in the process of force injure, its internal micro crack initiation extension and cracks collecting will produce the phenomenon of elastic energy release known as the acoustic emission signal. Acoustic emission signal parameters(ringing counts, energy, amplitude) can reflect the dynamic evolution process of rock internal micro crack in a certain extent. After different temperature effect, the relation curve of rock salt specimens uniaxial compression of the acoustic emission characteristics as shown in Fig. 2. Contrastively analyzing the curve relationship of between stress-strain and acoustic emission ringing count frequence and cumulative ringing counts were shown in Fig. 2.

Rock salts acoustic emission - stress - strain curve exist such features: Rock salt acoustic emission signal producing from the beginning loading the specimen compression failure, almost always have acoustic emission signal generated in the whole process; Acoustic emission rate and acoustic emission signal accumulative counts and stress-strain curve has a good 
Table 1 Experimental results under different temperature brine conditions

\begin{tabular}{|c|c|c|c|c|c||}
\hline $\begin{array}{c}\text { Specimens } \\
\text { number }\end{array}$ & $\begin{array}{c}\text { Temperature } \\
T,{ }^{\circ} \mathrm{C}\end{array}$ & $\begin{array}{c}\text { Elastic extremity } \\
\text { strength, MPa }\end{array}$ & $\begin{array}{c}\text { Extremity } \\
\text { strength, MPa }\end{array}$ & $\begin{array}{c}\text { Peak strain, } \\
/ \%\end{array}$ & Modulus, GPa \\
\hline $\mathrm{T} 1 \mathrm{a}$ & 35 & 9.62 & 37.45 & 6.43 & 2.69 \\
\hline $\mathrm{T} 2 \mathrm{a}$ & 35 & 9.83 & 31.67 & 6.33 & 2.71 \\
\hline $\mathrm{T} 1 \mathrm{~b}$ & 50 & 10.09 & 36.01 & 6.41 & 2.44 \\
\hline $\mathrm{T} 2 \mathrm{~b}$ & 50 & 9.16 & 32.92 & 6.07 & 2.22 \\
\hline $\mathrm{T} 1 \mathrm{c}$ & 70 & 11.13 & 36.63 & 6.41 & 3.7 \\
\hline $\mathrm{T} 2 \mathrm{c}$ & 70 & 8.47 & 31.72 & 6.51 & 2.62 \\
\hline
\end{tabular}
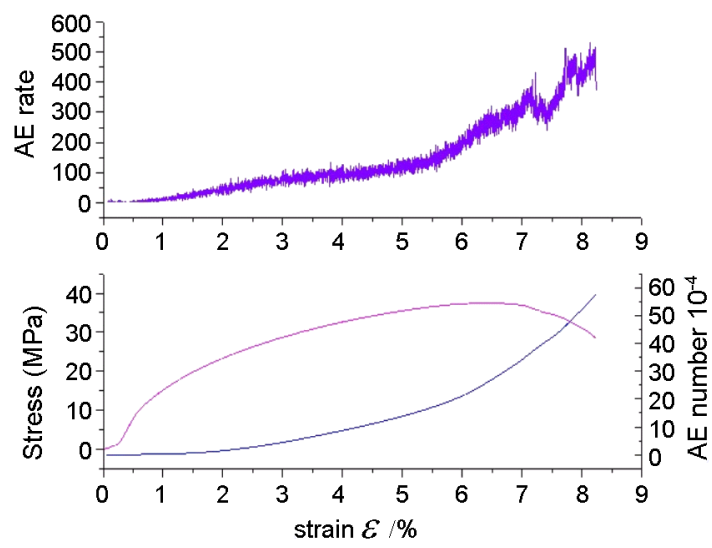

(a) temperature $35^{\circ} \mathrm{C}$ drying 2 days
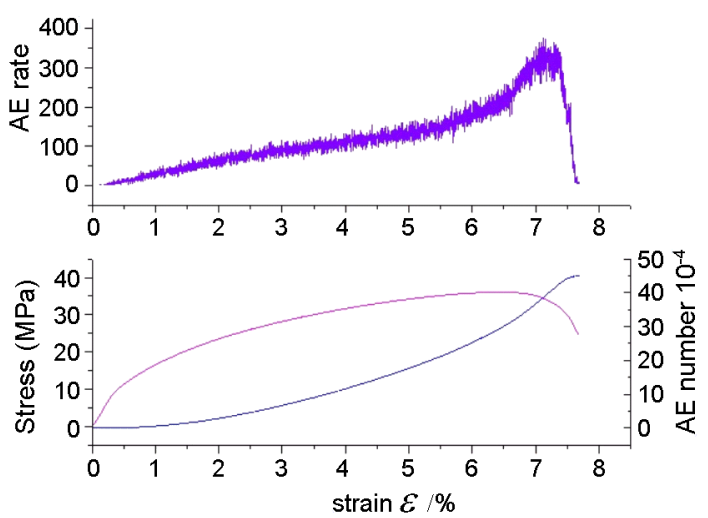

(b) temperature $50^{\circ} \mathrm{C}$ drying 2 days
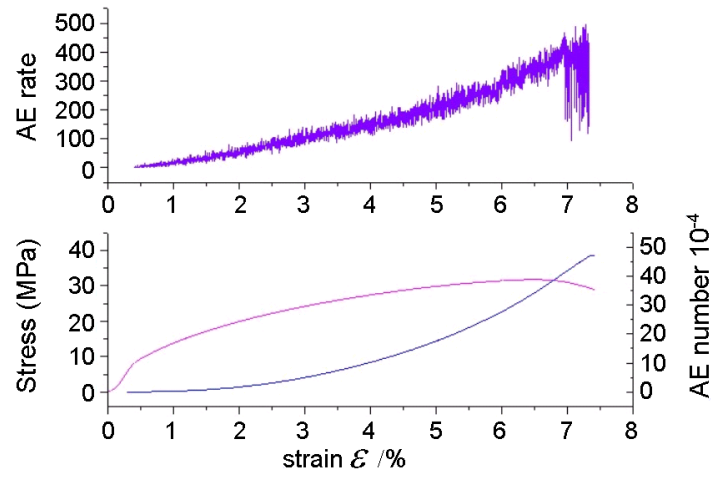

(c) temperature $70^{\circ} \mathrm{C}$ drying 2 days

Fig.2 Relationships of AE frequency, AE count and stress with strain

consistency; Acoustic emission rate increases with the continuous growth of the loading process. Based on the above characteristics and rock salts stress-strain curve characteristics, its could have a detailed analysis of rock salts after effected by temperature uniaxial damage acoustic emission characteristics.

There is no acoustic emission signal in elastic compaction stage, means rock salt specimens internal original crack and pore slowly closing under stress effecting. Due to the loading rate slow the internal opening crack slowly closing, only a tiny amount of acoustic emission signal produced. Plastic deformation and micro crack unstable propagation stage, acoustic emission signal frequency present a slowly increasing trend, and increase rate is slow. Acoustic emission rate does not appear obvious fluctuation change. In this stage, rock salt internal cracks were rapid derivative extension, collection, and form the main destruction of the main crack. Posterior destruction stage, acoustic emission signal frequency further rapid increase, its maximum generally appear at this stage, and acoustic emission signal frequency present a concussion type change. At this stage a large 
number of micro crack extension to assembled transfixion fracture plane, and fracture plane faulting and prompted a large number of acoustic emission signals to produce. This time rock has been destroyed, makes a lot of cracks in the process of pressing are mutual faulting extrusion at the same time produce a large number of secondary crack, and promote the acoustic emission signal generating.

Only after temperature short time effect on rock salt uniaxial acoustic emission- stressstrain curve features is basic similarity, what the difference is temperature rising. The total number of acoustic emission ringing counts of rock salt specimen will be reduced, its average acoustic emission rate also slightly decreased. Preliminarily infer the reasons of concretely produce is: When the temperature of the specimens rising, make rock salt crystal water chestnut softening, means when intercrystalline squeezing each other, the stress concentration cause elastic energy release on grain junction weaken, and that show up less of the acoustic emission signal. This and the rock salt rheology enhanced with temperature rising in the study of Chen Jianwen [7] on rock salt triaxial temperature test has certain consistency.

\section{Conclusion}

Rock salts under the condition of short-term temperature drying effect, its uniaxial compression characteristics change a little. When the rock salt specimens effected by temperature, it is hard to observe the change of compressive strength and strain value, illustrate that rock salt uniaxial mechanical properties influenced a little under the condition of temperature below $100^{\circ} \mathrm{C}$. Rock salt stress during the uniaxial compression - strain curves and acoustic emission - strain curves of variation has better consistency. the cumulative AE number was slightly reduced with temperature rise under the uniaxial compression process.

\section{Acknowledgments}

This research was supported by the China Postdoctoral Science Foundation (No. 2013M540620; 2015T80857).

\section{References}

1. NI Xiaohui, ZHU Zhende, J. Chin. Coal Soc., 36(2), 248, 2011.

2. Zhu Yuanguang, Liu Quansheng, Kang Yongshui, Chin. J. Rock Mech. Engin., 30(9), 1882, 2011.

3. Liu Shi, Xu Jinyu, Zhi Lepeng, Chin. J. Rock Mech. Engin., 32(2), 273, 2013.

4. Hu Xiong, Liang Wei, Hou Sijing, Chin. J. Rock Mech. Engin., 31(6), 1222, 2012.

5. S.T. Horseman, J. Handin, A.G. Duba, W. Durham, J.W. Handin, et al. The Brittle-Ductile Transition in Racks. Am. Geophys. Union, Geophys, Monogr, ser., AGU, Washington, D. C. 56, 103,1990

6. Raymond C. M. W. Franssen. Tectonophys., 223(2), 1, 1994.

7. Chen Jianwen, Yang Chunhe, Gao Xiaoping. Chin. J. Rock Mech. Engin., 27(11), 1986, 2005 ,

8. Jiang Deyi, Chen Jie, Ren Song, et al. Int. J. Rock Mech. Min. Scie,, 32(2): 0326, 2012. 